\title{
北朝鮮の「経済管理改善措置」と 中国の改革開放政策の比較
}

\begin{abstract}
今村弘子
北朝鮮は 2002 年 7 月に価格改革を主とする経済管理改善措置を開始した。同措置を中国の改革開放政 策と比較すると，同措置は順序を無視した改革であること，北朝鮮では金日成から金正日と政権が連 綿と続いていること，北朝鮮の経済があまりに困笨しており，インセンティブ・システムが㗢かない ことなどから，中国の改革開放政策と類似している点は少なく，北朝鮮の経済を改善させることは䨅 しい。

[キーワード： 経済管理改善措直, 中国との比較, 改革の手順, ハイパー・インフレ]
\end{abstract}

\section{1 北朝鮮の「措置」の内容}

2002年 7 月に北朝鮮が価格改革や為替レート の切り下げなどを含む,「経済管理改善措置」(以 下「措置」）を行ったとの報道がなされた。北朝鮮 の「措置」について, 中国の改革・開放政策と比 較しながら, 北朝鮮での「措置」の妥当性を考え る。

02年北朝鮮が行ったとされる「措置」は，01年 10月金正日が指示をだしたもので ${ }^{1)}$, 以下の内容 が含まれる。(1)経済管理を大胆に修正することと し, 計画については, 戦略的・国家的な重要な指 標は国家計画委員会が計画し, 月別計画や細部の 計画は地方の計画部門が計画すべきであり，(2)価 格は上級部門の監督の下に, 工場自らが制定すべ しとしている。また資材供給についても，社会主 義物資交流市場を組織, 運営させるようにすべき であり，(3) (これまでは) 経済部門幹部らが労働 力，物資，資金の浪費のいかんに関係なく生産と 建設のみを行えばよいという経済管理を行ってき たが，(今後は）資金・物資・労働力投入対比実利 2)をどれほど得たかを把挃することができるよう にしなくてはならず, 財政計画の方法と計算体系 を正しく確立し，財政が逼迫すれば生産経営活動 を促すようウォン（貨幣）による統制を強化すべ きである。さらに(4)分配の平均主義の排除，(5)貨 金, 無償支援の改善, (6)科学技術・情報産業の発
展, む含んでいる。

価格改革のなかで, 食糧に関しては, 絶対的な 不足から配給制を廃止することは難しく，配給制 を維持しながら価格の引上げだけを行ったようで ある ${ }^{3)}$ 。メはそれまでキロ当たり0.6ウォンで農 家から買い付け，0.08ウォンで販売していたため に逆ザヤになっていたのを，40ウォンで購入し， 43ウォンで販売することになった。もっとも 0.08 ウォンという販売価格の時でも実際には蘭市場 で, 50ウォン程度で売られていたわけであるから， 今回の一連の措置がとられる以前に闇市場で販売 されていた食糧の価格を「䦩」から表舞台の価格 にしたものと思われる。闇価格が跋扈していたた めに, 意味をなさなかった公定価格を引き上げて， 実際の価格にあわせたわけである。さらに豚肉は キロ当たり「覸市場」で，実際に60〜80ウォンで 売られていたので,それより高い110ウォンで買い 付けるとしている。価格改革は「農民市場」を閉 鎖させ，国営商店の機能を取り戻すことを目的と していた。

さらに重要工業製品と輸入品の価格について は高い倍率が設定されている。石炭1トンは改定以 前には1500ウォンであったものを44倍に，電力は 1, 000kwh あたり2100ウォンを60倍に設定した ${ }^{4) 。}$

価格改定に伴って新価格に相応する程度に給 料を引上げることになった。給与の引き上げに関 しては，炭鉱労働者の場合 30 倍，公務員では17〜 
20倍に引き上げられたようである。重労働者には 厚く, 非生産部門での賃上げは少なくなっている。

さらに給料を上げるかわりに家賃や水道代な ど基本的な生活費に関しては，これまで無料ある いはタダ同然であったものに相応の費用を支払わ なければならなくなった。市内バスの運賃は20倍 の 2 ウォンに, 住宅使用料は $60 \mathrm{~m}^{2}$ の場合, 1 ヶ月 で78ウォンに, 暖房使用料も同175ウォンと設定さ れた。

成果主義の導入に関しては，これまで「社会的 にタダが多く，平均主義をやってみると・・・勤 労者の労力的熱誠を貶めるようになった」ことか ら「働いたぶんだけ，稼いだぶんだけ，生活費を 厳格に計算して与える」ことを目指すことになっ た。

食糧価格引き上げに関しては，給料のなかで食 糧の值段が占める割合がわずか3.5\%にすぎないと 公式の面を強調しながら，一方で「最近数年間, 国家が食糧をまともに供給できなくなるや，多く の人々がすでに持っていた職業まで捨てて, 商売 などをしながら自分個人の利を埋め合わせること に走った」5) と実態面での問題点も諗識しつつ, 給料と物価の改定を行わなければならない理由を 述べている。今回北朝鮮で行われたのは，あくま で価格の改定であり，企業や農家が価格を設定で きる価格の自由化ではない。

また 8 月 1 日からウォンの対米ドル交換レート は 1 ドル=2.15ウォンから150ウォンに切り下げ, 外貨兌換券を廃止した。ただし 7 月以前の段階で あっても闇市場では 1 ドル＝200ウォン程度で取 引されていたとの報道もあり ${ }^{6)}$ ，切下げ幅は不十 分だった。

\section{2 改革の前提条件および手順}

北朝鮮はなぜこの時期に「措置」を行ったのか。 いうまでもなく経済状態が非常に悪化していたか らである。

北朝鮮は 90 年代になってから, 外部要因としな がらも，経済の恶化を率直に認めざるを得なくな っていた。しかし高度成長が続いていると公表さ れていた90年代以前より北朝鮮の経済は悪化して いたのである。北朝鮮の経済建設は建国直後から 中ソの援助に依存しており，中ソ，就くソ連から
の援助が減少すると，長期計画を達成することが できなくなるということが，60年代からすでに起 こっていた。また無理な繰上げ達成運動など経済 性を無視することが行われていたことも経済を悪 化させていた ${ }^{7)}$ 。それでもかろうじて経済活動は なされていたが，ソ連の崩壊や90年代半ばの自然 災害により，経済の悪化を北朝鮮自ら認めざるを 得ないほどになっていた。

98年には憲法が修正されて，非公有経済に対す る規制の緩和が決められたものの，99年の「国民 経済計画法」は，非公有経済の混乱によって，麻 㾝してしまった計画部門の経済を正常に戻すこと を目指すなど,経済運営には混乱がみられていた。

また前提条件として問題になるのは，果たして 現在の金正日体制が，金日成体制の延長上にある のか，金正日が独自の体制を築いているのか，と いうことである。もし金正日体制が金日成体制の 延長であるなら，前体制を否定するような「措置」 は行えず,小手先の変更にとどまることになるう。 金日成時代にも経済運営は金正日が担当していた と伝えられている。また軍事優先路線などは金日 成時代とあまり変化がないようにも見受けられ る。金正日体制の下でも，金日成は敬意を示す対 象のままであり，金正日体制は金日成体制の延長 にあると見た方がよいであろう。

中国の場合は文化大革命の終了, 4 人組の逮捕, 鄧小平の復活を受けて，文革時代の否定から「改 革・開放」政策は始まったのであった。10年にわ たる政治闘争に倦み疲れた人々にとって, 経済的 に豊かになれるという改革は大いに支持されるこ とになった。

また改革を行う際には，市場経済であろうが， 社会主義経済であろうが, 改革の順序 (sequence) が, 改革を成功させ得るか否かの大きな鍵となっ ている。もちろん初期条件によっても、国や経済 体制によっても「順序」は各々異なるものとなろ う。改革の順序についていえば，中国ではまず農 業部門から始まった。当時全人口の8割が農村にい たことから，農村での改革にまず着手されること になったのであるが，農業での改勒成功したこ とによって, 食糧生産が大幅に増加し, 食べ物が 豊富になったことから，人々が膚で感じられる豊 かな生活が「改革」によってもたらされたのであ 
った。さらに個人や家庭による農村での請負制は インセンティブ・システムの効果を最大限発揮し やすかった。

ところが北朝鮮ではまず価格改革から始まっ た。ところが実際の生産を回復させる手立てがと られていなかった。確かに貨金はあげられ，食糧 の買上げ価格も引き上げられたが，原材料やエネ ルギーもなく,化学肥料などもない状況のなかで， 工業にしても農業にしても生産を回復させること は困難だった。食糧の配給制度に関しては手をつ けることができないほど, 農業生産が悪化してい た。また軍事工業優先路線が続けられ，消費財生 産は回復の兆しすらない。北朝鮮の人々にとって みれば，おそらく「豊か小になる実感がないまま に，価格だけがつりあがるという生活感覚である う。農業でも，工業でも生産の回復が図られない まま価格改定が行われたことから，ハイパー・イ ンフレを招くだけにおわった。生産そのものの回 復を図らないまま価格改革を行うなど「順序」を 無視した改革が行われている。

\section{3 価格改革}

社会主義国では価格統制が行われていること から，目に見える形でのインフレは起こらない場 合が多い。しかしモノ不足の状態では当然のこと ながら「隠れたインフレ」が存在する。またモ， 不足のなかでも需要があれば非合法の売買も起こ りがちである。従って地下経済を生み出す温床と なる場合が多い。また価格を抑制するために政府 が財政補填を行うため，往々にして財政覀化もも たらした。

中国では50年代以降小幅な価格改定しか行わ れず，50年代以降小売物価指数が大きく上がった

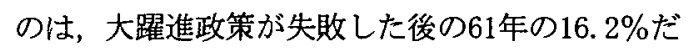
けであり，63年から72年までは（68年を除いて） マイナスであった ${ }^{8)}$ 。それ以降も改革開放政策が 開始されるまで，物価上昇の範囲は小数点以下に すぎなかった。歪な価格体系が続いたことから， 80年代半ばに洒格改革を迫られるようになった。 さらに改革直後, 農産物の大幅な価格引上げによ って，穀物などの増産をもたらしたが，価格イン センティブが予想外に働き，大增産になったこと から，財政負担が増加した。食糧という生活にお
いて基本的な物資さえも市場で売られるようにな ったが，このことは価格統制が一部緩和されるこ とを意味していた。また農産物の買い上げ価格が 引上げられた結果, 逆ざやが生じ, 財政補助金が 増加したことも価格改革を迫られる要因となっ た。

また84年から工業部門の改革が本格化したが， 価格体系が歪であったことから，農業のように劇 的な効果をもたらすことはできなかった。利潤上 納制を止め，所得税を課していく（利改税）ため には，価格改革は避けて通れない問題となった。 とくに問題であったのは(1)商品間の価格比が不合 理で, 原材料やエネルギ一の価格が低すぎたこと， (2)品質差が価格に反映されていないこと，(3)第三 次産業の料金が安すぎたこと ${ }^{99}$ ，であった。指令 性物資を逐次少なくする，あるいは工業製品に関 しては, 請負量以上に生産された産品に関して, 上下 $20 \%$ の制限はあるものの, 自由に価格をつけ られるという方法などを通じて価格は改定されて


物価上昇を記録した。物価があがる，二重価格に なる, あるいは品薄状態になるという過程で, 官 僚ブローカーが出現し，それらの不満も六・四事 件 (天安門事件)を起こす要因のひとつとなった。

このため価格改革は一旦中断するが, 90年代以 降順次准められ，92年以降，金融政策の失敗とも 相俟って,インフレが昂進することになったが(消 費者物価は93年 $14.7 \%, 94$ 年 $24.1 \%$ 上昇)，93年半 ば以降逐次公定歩合を引上げ，また不正融資の回 収を図るなどして，ようやく96年に8.3\% ${ }^{11)}$ と一 桁にまで引き下げることに成功した。しかしその 後も金融引締め政策が続いたことから，98年以降 デフレ傾向が続くこととなった。

中国の場合，価格改革は副作用はあったもの の，農業においても工業においても，生産量を增 やすことに一定の役割を果たした。しかし北朝鮮 の場合は，価格を引き上げても生産量を増やす役 割は果たせなかった。

\section{4 農業部門の改革}

中国での農業部門の改革は，それまでの人民公 社における集団農業から, 各農家が生産を請け負 う形態で始まった。この方式は77年より四川省や 
安徽省で始められたものであり，瞬く間に全国に 拡大した。さらにそれまで農産物価格は安く買い 上げられていたが，農民のやる気を刺激するため に買上価格も引上げられた。価格引上げはたとえ ば款物では平均 $20 \%$ 引げられ，さらに計画超過 買付分については（20\%のうえに）さらに $50 \%$ 上 乗せられた（販売価格については急激な引上げを 避けるため，国家が財政補助を行うことになり， 財政支出が増加した。なお83年時点のコメ，小麦 など食糧6種類の100厅（50キロ）あたりの平均買 付価格が23.57元に対し，販売価格は14.43元であ った ${ }^{12)}$ 。集団農業から個人（あるいは家庭単位） による農作業への回帰は価格政策と相俟って，ひ ろく農民に支持され，82年には人民公社は総て解 体された。また文革中に 3 億トン前後にとどまっ ていた食糧生産量は，84年には 4 億トンを突破し た。このように請負制の導入および買付価格の引 上げの効果は大きかったが, 政府にとっては逆ざ やの負担が大きくなったこと，および食糧生産が 急速に桩大したことから，85年からは食糧も自由 市場で販売されるようになった（ただし超過買付 け分の恩恵がなくなり，農民にとっては不利な価 格体系になったことから，その後数年食糧生産は 「徘䧃」する（すなわち生産が伸び悩む状態）こと になった)。なお請負期間は当初 3 年であったが, 期間が短いと収奪農業になりがちであることか ら，84年には15年に延長され，さらに 93 年には 30 年にまで延長された。

北朝鮮の食糧生産は, 90年代の大洪水によって 壊滅的な被害を受けたが，それ以前70年代からす でに「一日二食」運動をしなくてはならないほど 食糃事情は悪化していた。無理な密植のために地 カが低下したこと，「全国土の棚田化」により樹木 が伐採されたために土地の保水力がなくなったこ と，エネルギー不足から農業機械を動かすことが できない，あるいは新たに生産することもできな い状況になった。さらに工場の稼働率が低下寸る につれて，化学肥料の生産もできず適切な施肥が できないという状況も生じた。なお 70 年代に農業 生産を回復させるために試みられた干拓も，結局 塩害がひどく生産増には結びつかなかった。

このような状況を打破すべく, 北朝鮮でも 80 年 代末に，中国の農家請負制に類似した「家庭農場」
が試みられたが，うまくいかず，現在生産単位を 小さくする試みが行われている。96年に「合作農 場分組管理制運営改善措置」が公布され，97年よ り実施されることになった。しかしこれは全国的 には普及せず，結局中国的な請負制は北朝鮮では 根付かなかった ${ }^{13)}$ 。

北朝鮮の場合は, 気候条件も悪く, 優良種子や 化学肥料, 農業機械もなく, 物的インセンティブ すら与えられないような情況であり，生産単位を 大きくしても小さくしても「改革の成果」を出す ことは難しく, 生産体制改革以前の問題が大きく たちはだかっている。

\section{5 工業部門}

中国において，改革開放前の78年には工業総生 産額に占める国有企業（当時の呼び方は全民所有 制企業）の割合は77.6\%であり，工業部門の改革 とは国有企業の改革に他ならなかった ${ }^{14)}$ 。

中国では前述のように価格体系に歪みがあり, 企業努力が業績に結びつかない場合が多かった。 たとえば石炭採掘業では掘れば掘るほど赤字であ った。さらに社会主義国のなかで失業がないとい う前提のもと，労㗢力の受け血として国有企業が 余剩な人員を抱えていたこと，さらに赤字がでて も国家が補填してくれるという「親方日の丸」的 な体質のなかで，国有企業の経営効率はきわめて 悪かった。企業は利潤を国家に上納し, 必要な資 金は国家が供与するという利潤上納制度は，85年 に所得税を納める制度に変更され，それに伴って 必要な資金は銀行融資でまかなっていくことにな った。しかし当時は銀行も行政部門にいわれるま まに融資する（即ち企業の業績を審查して融資を 決定するという能力もない「金庫番」であったこ と，また企業の側も「返済」しなくてはならない という意思がなかったことから，今日まで続いて いる不良債権を累積させることになっていった。 余剩人員対策としては，80年代半ばから，それま での終身雇用から「契約制」がとりいれられ，失 業が公認される一方, 社会的セーフティー・ネッ トワークの一環として, 養老保険 (年金), 失業保 険，疾病保険などが導入されてきた。しかし古く からの工業基地である東北地方などでは，労働者 の高跘化が進み，離退職者の人数も多いため, 盖 


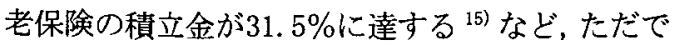
さえ苦しい企業経営を圧迫している状況である。

国有企業改革を進め，効率の向上を図らうとす れば，余剩人員を吐き出さざるを得ず，その結果 失業者が大量に生まれ，社会的な不安定性を増す ことになる。実際最近では東北地方で，職を求め ての示威運動が多発している。国有企業改革が進 展し，株式上場企業や民営化企業などが増加すれ ば，余剩人員を雇用し続けることが難しくなるた めに，失業者が増加するというジレンマに中国は 陥っている。しかしWT0に加盟し「大競争」の時 代に入った中国は国有企業改革を待ったなしで行 わなければならなかった。

なお中国では国有企業改革は期待通りには進 展していないものの，改革開放以降，新たに附加 された領域である郷鎮企業や外資系企業が，工業 生産で重要な役割を担い，工業生産そのものは順 調に増加していった（工業総生産額は78年の4237 億元から02年には11兆776億元（いずれも名目值） に增加)。しかし新たな領域が付け加わったことか ら,98年には工業全体に占める国有企業の割合は3 割を切ってしまった ${ }^{16)}$ 。鄉鎮企業は定義的には 「私有」ではなく「公有企業」ということになって いる。ムラなどの末端行政組織あるいは農民が共 同で出資して設立し，共同所有している企業だか らである（85年からは農民の個人所有の企業も郷 鎮企業に含まれるようになった)。実質的に一部の 人に私有化されているという別の問題があるのも 確かであるが，とくに公的な部門からの資金援助 を受けておらず，従って各企業は己の才覚によっ て経営しなくてはならず，そのため郷鎮企業では 創業も多いかわりに，倒産や閉鎖も多くなってい る。その意味では，企業経営は限りなく民営企業 に近いものになっている。また郷鎮企業の多くは 資金力が少なかったことから，計画経済の時代に はおろそかにされていた消費財を生産する企業で あったり，あるいはサービス業を担う小型企業が 多かったことも，人々の生活の質を豊かにするこ と役立った。

工業部門においては北朝鮮は民営化とは逆行 する動きを見せている。鈴木（p. 31）によれば99 年末から北朝鮮の代表的な大規模工場 - 企業所に つけられていた「連合企業所」「総合企業所」「総
合企業」の呼称が「工場」や「製鉄所」などに改 称され始め，また内閣值属の「総局」の名称が「管 理局」に改称される動きも始まった。鉿木は「連 合企業所』を単なる『企業』に降格した意図は, 企業コンプレクスの独立王国化を戒めて自主権を 制限し，中央管理をしやすくするところにあるの ではないだろうか」と指摘している。

北朝鮮では主要連合企業を解散させて中央の 管轄を強化しながら，非公有部門経済の拡散を黙 認するなど混乱した動きがみられる（工業部門の みでなく，対外経済部門においても，正式文書で は対外経済への依存度を低くするようにという一 方，主要部門に対し，国際経済組織と接触し，経 済援助の拡大を要請するようにとの要求がなされ るなど，経済の各分野が混乱状態にある） ${ }^{17) 。 ~}$

さらに北朝鮮の工業部門の改革を阻んでいる のは，「自主権が認められないとか「物的インセ ンティブを与えることを認めていない」という段 階の問題ではない。軍事工業に資金，原材料，エ ネルギーが優先的に配分されるような状態では, 民生部門の発展が著しく阻害されることはいうま でむない。また軍事予算は，公表された数字だけ でも財政の10〜15\%に達しており，他の部門に含 まれている（重化学工業などに含まれる予算の一 部は軍事に回されていると思われる）軍事予算を 含めると $30 \%$ 前後に達しているといわれている。 軍事に向けられる予算が膨大であることが，軍事 以外の工業や農業などの他の部門の経済を圧迫し ていることは容易に想像できることから，北朝鮮 経済の歪さが浮き彫りになっている。

\section{6 対外経済関係～開放政策}

中国が79年に発表した合弁法は15条と非常に 簡単であったことから，交渉の途中でしばしば内 部規定を楯に合弁相手から条件の変更が求められ たり，許認可が得られなかったという事態が生じ たことがあった。さらに当時の中国の合弁法では 合弁期間が15年と設定されていた。

このため中国でも79年に合弁法が発表になっ た直後は，当時の社会主義制度に資本主義の制度 が本当に受け入れられるのかとの心配があり，中 国の期待とは裏腹に外資導入はあまり進まなかっ た。ようやく外資導入が本格化したのは，84年に 
外資導入の細則が発表され，85年にプラザ合意が あった後であった。

しかし85年以前に西側の資本が中国進出を踌 躇している時代であっても，香港や東南アジアの 華僑・華人資本が中国人投資し，そのことによっ て，中国が西側商習慣を学習する機会を得ること ができたのであった。80年代前半には中国の直接 投資契約の 8 割前後を香港が占めていた。また香 港や華僑・華人資本の中には東南アジア諸国の経 済の主翼を担うほど，豊かな資金力を誇る企業も あり，実質的な面でも中国経済の発展に役立って いた。また中国と地縁・血縁関係がある香港や華 僑・華人企業もあり，西側資本がそれら企業と組 んで中国に投資をすると比較的スムーズに交涉が 進む場合もあった。香港や華僑・華人資本は直接 的，間接的に中国への投資環境を整備してきたこ とになる。

直接投資の導入に関する法律を，北朝鮮は84年 に発表している。プラザ合意の 1 年前であり，夕 イミングとしては絶好の時であったにもかかわら ず，外資が北朝鮮経済に大きな影響を与えるとい う事態は生じなかった。また北朝鮮も海外僑胞の 投資を奖励しているが，資本力・ネットワーク力 とも華僑・華人企業には及ばない。

北朝鮮も中国も外資導入政策が発表された当 初は輸出義務が課せられ，外貨獲得が主眼であっ た。つまり自国内の労㗢力を使った委託加工型の 外資導入が主であった。しかし中国では所得水準 が向上し，また外貨調節センターで外貨を調達す る道が確保されるに従って，次第に国内市場を夕 一ゲットとした直接投資が行われるようになっ た。この動向は中国のW T O加盟後一層加速する ものと思われる。流通や金融といったサービス産 業への開放も本格化するからである。「13億の市 場」はバラ色の幻にすぎないが, 13億の人口の $5 \%$ でも購買してくれるのであれば，欧州の一ヶ国の 人口に相当する程の大きな市場となる。

この点, 北朝鮮は国内市場があまり大きくない ことから，依然として委託加工型が主流にならざ るを得ないであろう。とくに北朝鮮は人口の規模 が小さいのみならす，一般の人々の可処分所得の 低さから，現状では国内市場をターゲットとする ことは無理である。
また日欧米資本の目が中国に注がれる状況が あるためか，北朝鮮への投資では，日本の在日朝 鮮系企業や韓国の財閥を含む企業の投資が多かつ た。しかしアジア経済危機以降，韓国の一部財閥 が経営危機に陷り，北朝鮮一の投資を手控えたり， 投資事業そのものがうまくいっていない場合もあ る。現代峨山が行っていた金剛山観光事業では, 観光客数の伸び悩みと現代側の経営悪化によっ て，北朝鮮への支払額を减額することになった。

北朝鮮の外資導入体制と，中国の外資導入体制 が最も異なるところは，政策そのものよりも，外 資受け入れに対する姿勢の違いであろう。鄧小平 は「空をあけたならば，新鮮な空気とともに八エ が入ってくるかもしれないが，それでもかまわな いと言ったと伝えられたが，それほど中国は新 鮮な空気 (外資) が入ってくるのを歓迎していた わけである。それに対し北朝鮮は一匹のハエでさ えも入ってくるのを恐れているようである。情報 統制を厳しく行っている北朝鮮では一匹の八工 (西側の情報)に対する兔疫力もないのかもしれな い。

さらに中国では経济改革と対外開放政策が同 時並行的に行われたことで，大きな成果をあげる ことができた。もし対外開放なしに経済改革が行 われていたならば，中国はしばしば発展途上国が 陷る「資本不足」の状態になっていただろう。ま た経済改革がなかったならば，㕍用や原材料調達 の自由, 貿易権の獲得，価格設定の自由などを獲 得することはもちろんのこと，中国という国内市 場に外資側はアクセス寸ることができなかったで あろうことから，外資側にとって中国の魅力は半 減していたろう。

対外貿易に関していえば，改革前は中朝とも国 家が一元的に行ってきた。中国では開放政策直後 は一般の地域は自ら稼いだ外貨の $25 〜 30 \%$ 留保 する権利が与えられた。ただし広東省や福建省な どは $100 \%$ 留保する権利を得ていたし，また計画外 に生産された財の輸出では一般の地域でも70〜 75\%を留保することができた。さらに大型企業に も貿易の権限を与えていった。しかしその過程で より多くの外貨を稼ごうとして值引き競争をして 安值で輸出したり，いくつかの省で同じようなプ ラントを重複して輸入するというような弊害も生 
じた。このため80年には輸出許可証制度がとられ るようになった。また当時は人民元レートが高め に設定されていた（公定レート 1 ドル =1.5元）た めに, 輸出業者に不利となったことから，81年か らは 1 ドル $=2.8$ 元の貿易外貨内部決済レートが 設定された。しかしこれが輸出補助金にあたると の批判がでたことから，84年末には一本化が図ら れ, 公定レートが2. 8元に引き下げられることにな った。なおこの後も中国は貿易赤字が搪大すると 為替の切り下げを行っている。また 80 年からは外 貨の裏付けのある外貨兌換券と人民元の 2 種類の 通貨が発行されることになった。本来この 2 種の 通貨は同価値であるはずであったが，次第に乘離 幅が大きくなり，経済活動に支障をきたすことに なったこと，またWT0 加盟もにらんで，93年末に 外貨兌換券は廃止され，人民元レートに統一され ることになった。

モノの輸出では世界の第4位（2003年）になっ ている中国に対し，北朝鮮は貿易相手国すらかな り限られた範囲にとどまっている。北朝鮮の場合, ミサイル問題等が噴出する以前から西側諸国との 貿易は極端に少なかった。建国直後以降では，旧 社会主義圏，とりわけ中ソとの貿易がほとんどで あった。しかしその北朝鮮が70年代初めに西側諸 国からプラントを導入した。しかし折悪しく石油 ショックの時期と重なったことから，プラント代 金は高騰，反対に北朝鮮の外貨獲得源である非鉄 金属の価格は暴落し, 北朝鮮はプラント代金を払 うことができなかった。日本をはじめ，西欧の銀 行団との債務繰り延べ交涉もなされたが, 結局支 払いの約束は守られなかった。このため日本企業 のなかで80年代になって貿易保険を受け取る企業 が相次ぎ，それ以降北朝鮮との貿易で日本の業者 は貿易保険をかけられなくなってしまった。この ような状況では，一般の企業は日朝貿易に参入し たがらなくなっている。

もともと北朝鮮は市場としても狭く，輸出市場 としての魅力も乏しかったことから，西側との貿 易も単発で増加することはあっても，傾向的には 少ないままである。

米国も北朝鮮に対する「テロ支援国家」の指定 をはずしておらず，戦略物資，ハイテク物資が輸 出されるのを警戒し，輸出には財務省の許可を必
要としている。実際に米国から輸出されるのは人 道的支援物資のみである。

北朝鮮では84年に輸出拡大のために貿易港を 增加させ,また国境貿易む行われるようになった。 88年対外経済委員会が設立され，同委員会の下に 貿易部と，新設された合営工業部が所属すること になり，あわせて地方の対外貿易権限も拡大され た。

90年代になってソ連・東欧，中国の変化に伴っ て，北朝鮮と社会主義国との貿易もそれまでのバ 一ター貿易からハードカレンシーによる決算を行 わざるを得なくなってしまった。さらに北朝鮮の 貿易の第一位の相手国であったソ連との貿易も， ソ連の崩壊とともに，10分の 1 に縮小してしまっ た。北朝鮮の貿易相手国は社会主義圈から東北・ 東南アジアに変わらざるを得なくなっていった。 92年に北朝鮮は「貿易第一主義（あわせて農業第 一主義, 軽工業第一主義)」を提唱し，また加工貿 易や，中継貿易の利用などを呼びかけた。また政 務院直属の貿易商社のほかに, 社会安全部, 保健 部，国家保衛部，人民武力部なども貿易商社を設 立させたことから，全国貿易公司の数は80年代の 39 社から 90 年代には 100 余社に增加，さらに各道・ 市行政委員会, 人民委員会も自分自身の貿易商社 を設立した ${ }^{18)}$ 。

地方への貿易権限の委諼や貿易権の多元化と いうことに関しては，北朝鮮も中国と同じ道を進 んでいるようにみえるが，北朝鮮の場合致命的な ことは，輸出できる産品が十分には生産されてい ないことである。そのような状況下で，貿易商社 が多くなることは外に対しては輸出する機会は増 えるかもしれないが，少ない商品の取り合いが起 こり，あるいは地域エゴイズムが起こることが予 想され，また国家として外貨収入をきちんと管理 できない可能性も高い。

国内経済が低調であることから，輸出産品を生 産することができないこと，さらに相手国の制約 もあることから，北朝鮮にとって対外貿易の問題 は，貿易体制改革以前の問題である。

\section{7 北朝鮮改革の行方}

北朝鮮は今後さらに改革を進展させようとし ているのであろうか。現状ではきわめて中途半端 
なものに過ぎず，経済の回復どころか，さらなる 悪化を招いている。䦩市場を閉鎖し，国営商店で の販売体制に戻すことを試みたのであるが，国営 市場で販売するモノがなければ，少ししかないモ ノはさらに梁い闇の市場にもぐることになり,一 般の人々の生活はさらに苦しいものになっていく であろう。このため一旦閉鎖された闇市場も 2003 年には「総合市場」として復活させざるを得なか った。03年の国家歳入は增加しており，「措置」の 効果があったようにもみえるが，これは「人民生 活公債」を発行したためであり，実態経済がよく なったからではない。

また価格引上げにあわせて給料を大幅に引上 げたとされるが，それは人々を勤務時間通り職場 に拘束することを意味しており，これまで副業に よってからうじて生活を支えていた状況がなりた たなくなっていることを意味している ${ }^{19)}$ 。価格を 上げても「工場に電気が来るのは週 4 日だけ，そ 㞦も 1 日 2 時間」 ${ }^{20)}$ という電力・資材不足はその ままなのである。北朝鮮で現在何よりも必要なの は，モノの生産，就く食糧生産の回復である。

モノの生産の回復を図る措置をとらずに，価格 改革を行うという順序を無視した改革を行ったこ とによって, 北朝鮮では八イパー・インフレが起こ った。またその過程で，何らかの形で外貨にアク セスできる者や，中国に親戚がいるなどして，中 国との間で貿易（密貿易を含む）ができる者は， 貿易によって入手したモノを「総合市場」で売る こともできるようになった。このように何らかの 「機会」がある人とそうでない人の所得格差が增し ていったことと思われる。

経済回復のためにはどうすべきか。もちろん日 朝の国交が樹立し，日本からの経済協力が行われ る状況になったならば，インフラの建設などが行 われ，経済発展の歩みは変わってこよう。ただし たとえば発電所建設を援助しても，電力消費地ま での送電線も老朽化しており，送電線までも設置 し直さなくては意味をなさないことになる。

改革の実をあげるためには，モノの生産を增や すことが肝要であろう。北朝鮮の現状で人々が豊 かさを実感できるのは，何より食糧が増加するこ とであろう。そのため北朝鮮ではまず食糧生産を 増加させるための傾斜生産を行わなくてはならな
いだろう。中国で1960年代，大躍進政策の失敗の 後「調整政策」がとられ，食糧生産の回復が図ら れたが，北朝鮮でも同じような政策が必要ではな いか。

中国では急ぎすぎた社会主義化政策である大 躍進政策の結果，1500万人もの餓死者がでた。こ のとき劉少奇と鄧小平によって執られて政策が 「調整政策」である。まず人々の「食」の問題を解 決するために「三自一包」，すなわち自留地や自由 市場，および損益自己負担（自負盈㱆）と請負生 産（包産到戸）を認めるという政策がとられた。 また工業生産においても農業を支援するための工 業の発展，すなわち化学肥料や農業機械の生産の 回復を優先的に図ったのであった。

北朝鮮でも「食」を確保する政策がまず必要て ある。自留地を増加させる，あるいは請負制にす ることによって,農家の裁量権を増やすとともに, 現状では貴重な外貨を使って，優良種子を輸入し なければならないかもしれない。また工業でも化 学肥料や農薬の増産を何よりも先行させることに よって,農業生産を回復させることが必要である。 北朝鮮は寒冷地であり，耕作地も少ないが，天候 に応じて種を蒔き，施肥し，水遣りをするといっ た科学的・合理的に管理を行えば，農業生産は回 復できるはずである。

たとえば北朝鮮の北隣の吉林省の収量はトウ モロコシで $5970 \mathrm{~kg} / \mathrm{ha}, コ メ て ゙ 5554.7 \mathrm{~kg} / \mathrm{ha}$ であ る。北朝鮮の耕作地は，畑 140.7 万へクタール，水 田58.5万人クタールあり，もし北朝鮮で吉林省並 の収量が得られれば，トウモロコシ840万トン，コ メ325万トンが収穫されることになる。

当然無理な密植運動などで, 地力は衰えている と思われるので，吉林省並の収量は得られないで あろうが，密植をせず，水管理や施肥を合理的に 行えば，たとえ吉林省の半分の収量であっても， 合計582.5万トンの収穫が得られることになる。

ある程度農業が回復したのなら，もともと「南 農北工」といわれたように，北朝鮮には鉱産物資 源もあることから，石灰や無煙炭などの採掘を行 い，エネルギー生産の増加を急ぎ、確実に民生用 と輸出用にまわす必要がある。それとともに，農 産物を原料とした軽工業も興し，さらに労働集約 産業であり，設備投資が少なくてすむ，縫製業の 
ような輸出産業を興す必要がある。

さらに本来ならば，同時に資本不足を補うため に外資の導入が必要である。ただし情報の浸透と いう副作用は，現状の北朝鮮にはきつすぎるかも しれないし，政情が不安定なままでは外資側の積 極性を期待するのも難しい。しかし資本不足を補 う妙案は外資導入しかないだろう。

ともかく現在のように手順を無視した改革は, 八イパー・ンフレを招き，その過程で所得格差の 桩大を招くだけであることから，実際のモノの生 産の回復を図ることが必要である。

（富山大学極東地域研究センター）

\section{注}

1)「北朝鮮政策動向」Vol. 10 (2002年 8 月 31 日), pp. 4 一6。より詳細な内容紹介は「強盛大国建設の要求に合 わせ社会主義経済の管理を改善強化することについて」 （金正日）『世界』2004年11月，pp. 238-249。

2）姜日天によると北朝鮮における実利とは，「社会主義 から逸脱しない範井内でなるべく多くの実利を獲得す るという消極的な意味合いではなく，社会主義計画経済。 こそ実利獲得に不可欠の大前提であり，だからこそ社会 主義の原則を堅持するという強い意志が表明されてい る」という(朝鮮民主主義人民共和国における経済管 理改善措直の解釈について」『同胞経済研究』2002年冬 第 7 号)。

3）http://www.bekkoame.ne.jp/ro/renk/kaidai.htm（「価格と 生活費を全般的に改定する国家的措置をよく知り, 強盛 大国建設を力強く早めよう」と題する講演で，2002年 7 月に金正日によって指摘されたとされている。

4）改定された価格や賃金および為替レートについては, 注 3 のほかに, 『朝日新聞』2002年 8 月16日，ラデオプ レス「北朝鮮の現況 2004」p.324など。ただしラヂオ プレスでは, コメの販売価格は44ウォンとされている。 また『朝日新聞』の記事は 8 月 15 日付けの中国『環球時 報』によっている。

5）注1に同じ。

6）『朝日新聞』2002年 8 月 16 日。

7）北朝鮮は建国直後から中ソ, 就くソ連の援助に依存 した国家建設を行ってきた。そのため中り論争のあおり を受けてソ連の援助が減少した 60 年代から国家建設は 撂炡をきたすようになった。林（p.41）によれば，ソ連 の北朝鮮一の年平均援助額は51年から60年までは8180 万ドルであったが，61〜70年には4245万ドルに減少して いる。一方 Yuri I. Ognev（1983、p. 355）によれば，ソ連
の援助が减少し, 北朝鮮が西側からプラントを導入した 後の82年の時点でさえ，北朝鮮の経済に締めるソ連の援 助の割合は，エネルギー加工で $68 \%$ ，原油で $50 \%$ ，鉄銅 で33\%などとなっている。ソ連の援助が北朝鮮に経済に 与える影響が大きいことがわかり，援助が減少したこと によって，60年代以降，北朝鮮経济の成長は困難になっ てきた。また 62 年からは四大軍事路線が採択され，全国 土の要塞化の掛け声のもと, 軍事施設が地下に移転 - 建 設されたことによって膨大な資金が費やされ，また全人 民の武装化によって，頻繁に軍事訓練がなされたことか ら，労働力が不足し，生産活動に支障をきたした。この ため，7 力年計画（1961〜67年）は 3 力年の延長を余儀 なくされている。このほか千里馬連動などの精神主義的 な運動の展開など, 60年代には北朝鮮の経済はすでに悪 化していたのである。

8)『統計資料汇编 新中国五十年』p. 21.

9）石原享一「価格改革」(小島麗逸編（1988年）所収）、 p. 165 .

10）84年の「国営工業企業の自主権を一段と払大するこ とに関する整定規定」にて上下 $20 \%$ の幅で価格を自由に 設定することが認められた。

11) 注 8 に同じ。

12）『岩波現代中国事典』p. 543.

13) 林 (2000)、p. 131.

14) 注 8, p. 36.

15）『中国信息報』2001年11月22日，同記事によると接 け金が最も低いのは広東省の珠海市で，15\%である。

16）注14に同じ。2002年の数字は『中国統計年鑑 2003』 p. 459.

17）張宝仁, 王新㓮「浅析近来朝鮮経済発展理論与政策 出現的新変化及其趨勢」『東北覀論壇』2004年 3 期、p. 51 .

18) 林 (2000)、pp. 253-254.

19）『朝日新聞』2004年 7 月 1 日.

20）『読売新聞』2003年 8 月23日.

\section{参考文献}

今村弘子（2000）『中国功見た北朝鮮経済事情』朝日 新聞社.

小島麗逸編（1988）『中国の経済改革』勁草書房.

鈴木典幸「1999年の国内経済」『北朝鮮の経済と貿易の 展望』日本貿易振興会.

梁文秀 (2000)『北朝鮮経済論』信山社. 林今淑（2000）『朝鮮経済』吉林省人民出版社.

Ognev, Yuri I. (1983) "Contemporary Soviet-Korea Relations", Ilpyong J. Kim ed., Korean Challenges and American Policy, Paragon House, pp.349-360. 


\section{Abstracts}

The Determinants of the Inflation Rate in Transition Countries - A Panel Data Analysis Takeshi Inoue (Graduate School of Economics, Kobe University, Ph.D student)

The theoretical literature points out that inflation targeting and the exchange rate peg have the advantage of lowering the inflation rate. Controlling for the other relevant variables, this paper estimates the effects of these policies on the inflation rate in 20 transition countries during 19952003 by using regressions on panel data. The main finding is that inflation targeting and the exchange rate peg appear to have been effective in lowering inflation rate even in transition countries.

Political Economic System and Food Entitlement in North Korea : Su-ryong (the Leader) economy and Hierarchy of Entitlement

Kwang-min Jeong (Nagoya University Graduate School of Economics, Ph.D student)

This article attempts to analyze the correlation between Su-ryong economy that is a core sector in North Korea's political economic system and food entitlement as a study of North Korean urban famine. In North Korea, Public Food Distribution system is characterized by hierarchic structure that privileges the ruling class, especially Su-ryong and his families. The economic basis to ensure the privilege of the ruling class is the Su-ryong economy.
Micro Foundation of Worship of the Kims

Makoto Kurosaka (Osaka University of Economics)

It is well known that worship of the Kims has been strengthened in North Korea. This paper analyzes this mechanism. The paper proposes two kinds of models which depict the North Korean system. The first one is a case where North Korean authorities can directly decide the labor allocation of people. The second one is a case where North Korean authorities make contracts with people. The result shows that low levels of reservation income is the origin of the strengthening worship of the Kims.

NORTH KOREAN ECONOMIC ADJUSTMENT POLICY : A COMPARISON WITH CHINESE ECONOMIC REFORM POLICY

Hiroko IMAMURA (Center for Far Eastern Studies, Toyama University)

In July 2002, North Korea announced a series of economic adjustment policies. This paper compares the adjustment policy of North Korea with the reform policy of China. North Korea, unlike China, had no real change in the political regimes and, therefore, it was inevitable that the reform would not be very comprehensive. In any reform, a proper "sequence" of reforms" is important. North Korea ignored the proper sequence of reform. For instance, in North Korea price reform was implemented first without securing an adequate supply of food and consumer production despite an acute shortage of supply in 
these goods. The results of the adjustment policy were hyper-inflation and a wider gap in income distribution. 